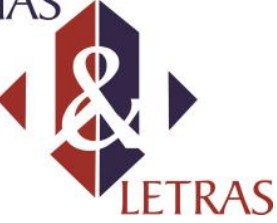

\title{
Patativa do Assaré: Um Olhar Fenomenológico Sobre 0 Espaço de Sua Poética
}

\author{
Patativa do Assaré: a phenomenological look about the space in \\ his poethic \\ Daniel Conte* \\ * Universidade Feevale, ICHLA, Novo Hamburgo-RS, 93352000, e-mail: \\ danielconte@ feevale.br \\ Rafael Hofmeister Aguiar** \\ **Universidade Federal do Rio Grande do Sul, UFRGS, Porto Alegre - RS, 90040- \\ 060, e-mail: rafael.aguiar@ rolante.ifrs.edu.br
}

RESUMO: Este trabalho aborda a imagem da casa e as suas possíveis nuances de habitação, através da fenomenologia bachelardiana, figuradas na poética de Patativa do Assaré, poeta cearense que traz em seu fazer literário a cultura popular sertaneja. Salienta-se a importância do sertão como lugar de sonho para o sujeito lírico representado nos poemas e a segurança que esse espaço oferece às vozes que se enunciam. Nesse espaço, os traumas são revividos e ressignificados desde um movimento de produção atmosférica do sentido, o que significa que o locus enunciado pela memória ergue, em si e desde si mesmo, um efeito de sentido enquadrante do sujeito que o conforta e possibilita o sonho.

PALAVRAS-CHAVE: Patativa do Assaré. Fenomenologia. Poética. Sertão. Casa.

ABSTRACT: This article approaches the image of the house and its possible nuances of habitation by Bachelard phenomenology, figured in Patativa do Assaré's poetry, a poet from Ceara who brings in his literary writing the popular backcountry culture. Stresses the importance of the sertão as a dream place for the lyrical subject represented in the poems and the security that the space offers to the voices that enunciate. In this space, the traumas are revived and reinterpreted from a movement of atmospheric production of meaning, which means that the locus enunciated by the memory raises, itself and from itself, a framed effect sense of the subject who comforts and enables the dream.

KEY WORDS: Patativa do Assaré. phenomenology. Poetic. Sertão. Home.

\section{À GUISA DE INTRODUÇÃO: A CASA E O ESPAÇO BACHELARDIANOS}

As imagens bachelardianas se condensam e permeiam a função de habitar a casa na poética de Patativa do Assaré. Para o sujeito lírico habilitado pelas potencialidades do sonho e do devaneio, o fenômeno se concretiza no sertão, espaço que concentra e 


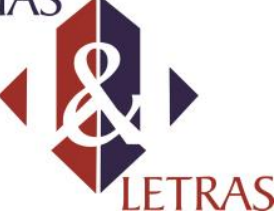

funcionaliza as imagens do ninho, da concha e dos cantos, os quais configuram o noturno Bachelard (2008). É n'A poética do espaço que o autor busca estabelecer uma filosofia da poesia, entretanto, ao contrário do que se possa imaginar, esse movimento não se dá pelo racionalismo filosófico. Para alcançar seu objetivo, o autor se vale da fenomenologia como método de investigação e de análise das imagens poéticas e da capilarização pictórica primitiva que se estende ao olhar humano. Nessa ordem, a fenomenologia a que Bachelard convida à análise é um fenômeno da consciência imediata da imagem poética, que procura identificar como a representação em si repercute no interior mais profundo do sujeito que se constitui como ouvinte ou leitor.

Bachelard assevera que para "esclarecer filosoficamente o problema da imagem poética, é preciso chegar a uma fenomenologia da imaginação. Esta seria um estudo da imagem poética quando a imagem emerge na consciência como um produto direto do coração, da alma, do ser do homem tomado em sua atualidade" (BACHELARD, 2008, p. 2). A citação evidencia que a perspectiva do autor é ontológica, uma vez que o filósofo se volta às imagens poéticas que estabelecem uma funcionalidade de imersão no universo ôntico do sujeito que as escreve e/ou as lê, ou seja, essas figurações poéticas atuam como produtoras de efeitos de sentido que favorecem a colocação do ser no espaço e no tempo, levando-o a protagonizar a própria experiência íntima. No entanto, o autor foge da pretensão de investigar todas as imagens possíveis; ele delimita o seu universo de pesquisa ao exame das imagens simples, aquelas que manifestam um espaço de felicidade, o que vai nomear de topofilia, projetando os valores humanos daqueles espaços protegidos, operadores de refúgio para o ser. As palavras do autor explicam melhor essa relação:

nosso campo de exame tem a vantagem de ser bem delimitado. Isso porque pretendemos examinar as imagens bem simples, as imagens do espaço feliz. Nessa perspectiva, nossas investigações mereceriam o nome de topofilia. Visam determinar o valor humano dos espaços de posse, dos espaços defendidos contra forças adversas, dos espaços amados" (BACHELARD, 2008, p. 19, grifos do autor).

Em razão de os espaços aludidos, nas fronteiras do seu espectro de investigação, construírem-se como espaços de proteção, sua poética é norteada pela instauração/exploração da imagem da casa, local de refúgio, de amparo e trânsito livre para o sujeito que recolhe os sonhos semeados e regados na materialidade dos espaços domésticos. Aliás, é importante dizer que a casa é a imagem que caracteriza o que o filósofo chama de função do habitar, o que será mostrado nos poemas de Patativa, uma Volume 18 


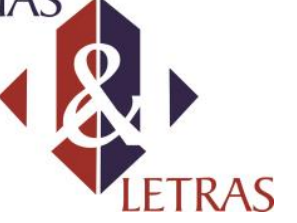

vez que "todo espaço realmente habitado traz a essência da noção de casa" (BACHELARD, 2008, p. 25).

É por esse motivo que o fenomenólogo inicia a sua explanação, no primeiro capítulo d'A poética do espaço, a partir da perspectiva arquitetônica da casa, imagem poética primeira do habitar e figura permanente na memória do ser. Seja qual for o espaço que se habite, a lembrança, a imagem da casa primeira é guardada e ritualizada na enunciação de cada nuance discursiva constituinte do sujeito-habitador, de cada ser que canta o espaço íntimo e que a canta como espaço de subjetivação. A casa em que se habitou na/a infância é possibilitadora do sonho e, por conseguinte, do devaneio. Naquele/nesse/neste espaço os traumas são revividos e ressignificados desde um movimento de produção atmosférica, o que quer dizer que o locus enunciado pelas dobras da memória ergue, em si e desde si mesmo, um efeito de sentido comportador do sujeito.

A casa pode ser vista, nesse sentido, como o grande berço, local de aconchego e proteção desde o nascimento do sujeito/ser (o que não se atrela, necessariamente, à cronologia), constituindo-se em um paraíso material, em que "a vida começa bem, começa fechada, protegida, agasalhada no regaço da casa" (BACHELARD, 2008, p. 26). Tais lembranças, as lembranças da casa natal-habitada, resguardam-se na memória, impregnam-se no inconsciente, acompanhando o indivíduo ao largo de sua vida, sempre retornando a ela em seus devaneios e, quando mais sólida é a lembrança, mais habitado e fazedor de sentido foi o espaço.

Essa casa é o canto do mundo em que o ser vive, plenamente, a função do habitar. Esse quinhão se constitui, de acordo com Bachelard, como um verdadeiro cosmo do sujeito. Diz ele que

é preciso dizer como habitamos o nosso espaço vital de acordo com todas as dialéticas da vida, como nos enraizamos, dia a dia, num 'canto do mundo'. Porque a casa é o nosso canto do mundo. Ela é, como se diz amiúde, o nosso primeiro universo. É um verdadeiro cosmos. Um cosmos em toda a acepção do termo" (BACHELARD, 2008, p. 2).

O cosmo em que se edifica a casa é como o mundo externo: um sitio que se complexifica, que produz no comum-vulgar um efeito de descartabilidade semântica. A casa é um espaço feliz, sem embargo guarda particularidades e mistérios, representados pelo porão e pelo sótão, denunciando uma polarização verticalizada. É 


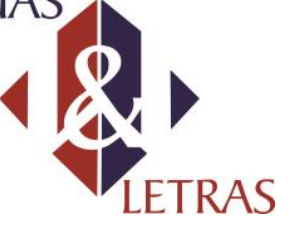

graças à casa que um grande número de nossas lembranças estão guardadas; e quando a casa se complica um pouco, quando tem um porão e um sótão, cantos e corredores, nossas lembranças tem refúgios cada vez mais bem caracterizados. A eles regressamos durante toda a vida, em nossos devaneios" (BACHELARD, 2008, p. 27-28).

A casa natal hierarquiza as funções de habitar os espaços: os espaços sólidos e os debilitados. É como se se revivesse, constantemente, a casa primeira, que se encontra inscrita nos sujeitos e são as digitais de sua alma. Todas as outras casas pelas quais se pode passar, não se elevam além de variações do espaço primeiro em que se viveu; a casa da puerilidade se inscreve no indivíduo de forma física: é uma matéria dentro de uma matéria. É uma confluência de lembranças almificadas em um corpo que a tem como tatuagem permanente nas camadas mais profundas do seu ser. Essa relação se constitui em uma dimensão ontológica do existir. Consoante Bachelard (p. 34), “a casa natal gravou em nós as hierarquias das diversas funções de habitar. Somos o diagrama das funções de habitar aquela casa, e todas as outras não passam de variações de um tema fundamental". A confluência pictórica da casa, antes enunciada, concretiza-se na verticalidade desse espaço e surge, então, o que antes referimos: a polaridade entre o porão e o sótão. Temos a imagem espacializada do sótão, representando a racionalidade, e o porão, atrelado à irracionalidade.

A verticalidade é proporcionada pela polaridade do porão e do sótão. As marcas dessa polaridade são tão profundas que, de certo modo, abrem dois eixos muito diferentes para uma fenomenologia da imaginação. Com efeito, quase sem comentário, pode-se opor a racionalidade do teto à irracionalidade do porão (BACHELARD, 2008, p. 36).

O porão, na organização fenomenológica dessa dicotomia, materializa a insegurança e o medo do homem diante de suas lembranças profundas, as que habitam a casa do ser, construindo-se como parte de seu ôntico universo. Essas lembranças de caráter inconsciente são as que o homem prudente junguiano, tomado como parâmetro por Bachelard, procura fugir, porque ao ouvir barulhos no porão, se dirige ao sótão para ver se não há ladrões.

Em vez que enfrentar o porão (inconsciente), 'o homem prudente' de Jung procura a sua coragem no álibis do sótão. No sótão, camundongos e ratos podem fazer o seu alvoroço. Quando o dono da casa chegar, eles voltarão ao silêncio da toca. No porão agitam-se seres mais lentos, menos saltitantes, mais misteriosos. No sótão, os

Volume 18

Número 40 


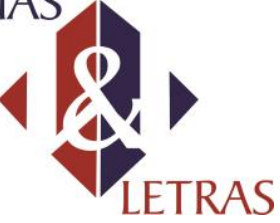

medos 'racionalizam-se' facilmente. No porão, mesmo para alguém mais corajoso que o homem mencionado por Jung, a 'racionalização' é menos rápida e menos clara; nunca é definitiva. No sótão, a experiência diurna pode sempre dissipar os medos da noite. No porão há trevas dia e noite. Mesmo com uma vela na mão, o homem vê as sombras dançarem na muralha negra do porão (BACHELARD, 2008, p. 37-38, grifos do autor).

A fuga do porão, ou melhor, o [des]movimento de adentrar esse espaço se dá pelo fato de o homem buscar viver as lembranças felizes, tentando escapar daquelas de onde se oriundam tristezas causadas pelo calafrio que se transforma em medo cósmico. Diz o autor que sentimos "claramente que esse calafrio já não é humano; é um medo cósmico, um medo antropocósmico que faz eco à grande lenda do homem entregue às situações primitivas" (BACHELARD, 2008, p. 41). O sujeito, nessa ordem, em vez de ir para o porão, movimenta-se para o sótão, espaço em que pode encontrar uma solidão feliz, já que tranquila. Nas palavras de Bachelard (2008, p. 43, grifos do autor), "a escada do sótão, mais abrupta, mais gasta, nós a subimos sempre. Ela traz o signo da ascensão para a mais tranquila solidão".

A casa funciona como a forma plena do habitar, pois proporciona ao homem a possibilidade de encontrar um refúgio que lhe protege do mundo exterior.

É preciso chegar à primitividade do refúgio. E, para além das situações vividas, cumpre descobrir situações sonhadas. Para além das lembranças positivas que são material de uma psicologia primitiva, é preciso reabrir o campo das imagens primitivas que talvez tenham sido os centros de fixação das lembranças que permanecem na memória. Pode-se demonstrar as primitividades imaginárias mesmo a respeito desse ser sólido na memória que é a casa natal. Por exemplo, na sua própria casa, na sala familiar, um sonhador de refúgio sonha com sua cabana, com o ninho, com os cantos onde gostaria de se encolher como um animal em sua toca. Vive-se assim em um além das imagens humanas (BACHELARD, 2008, p. 47).

Como signo de proteção e refúgio, a casa recebe a funcionalidade profunda do habitar, sendo a base para todas as outras imagens espaciais que podem traduzir a sistemática dos locais de amparo para o sonhador, ou seja, daquele que está habilitado para compreender a imagem poética. É desde esse contexto fenomenológico de espaço e lembranças que pretendemos analisar a figuração do sertão, imagem constituinte na obra poética do poeta cearense, à luz da significação bachelardiana. 


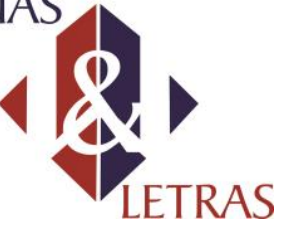

\section{SERTÃO: IMAGEM E LEMBRANÇA NA POÉTICA DE PATATIVA}

Nos poemas de Patativa de Assaré, é como constructo de um espaço feliz que o sertão se manifesta. Retratado como o espaço em que se quer viver e em que se pode sonhar, é na imagem constituída do sertão que o sujeito transita com tranquilidade. Para o sujeito lírico dos poemas, mesmo que o sertão seja um lugar de privações e de emergências diárias, desenha-se como a casa onde se deseja estar, como espaço que se anseia, uma vez que figura como a transição do alheio-extemporâneo para o íntimosincrônico. Nessa funcionalidade, o sujeito habita todas as potencialidades do imaginário e o "espaço sertão" dá forma à casa primordial dos eus que habitam os signos constituintes da materialidade poética do autor.

A dimensão do habitar o sertão como casa primeira fica evidente na quadra inicial (espécie de mote) do poema Cante lá que eu canto cá - que funciona como um manifesto meta-poético de Patativa. Em uma inversão da antítese de Gonçalves Dias (1995), cá e lá, o sujeito lírico opõe duas formas de habitar não só a do espaço físico, mas, também, a da palavra, a do fazer poético.

"Poeta, cantô da rua,

Que na cidade nasceu,

Canta a cidade que é sua,

Que eu canto o sertão que é meu" (ASSARÉ, 2004, p. 25).

Ao poeta só é dado o direito de cantar o espaço que lhe oferece o aconchego e a proteção da casa, que lhe proporciona o sonho e o devaneio, tornando manifesta a relação de propriedade que aparece na enunciação do poema, um movimento de apropriação natural se pensarmos na fixidez funcional da imagem de origem. Desse modo, ao poeta cantor da rua só lhe cabe como objeto aquele espaço que, de certa forma, lhe constitui, ou seja, lhe é autorizado poetizar sobre o urbano, e não sobre o sertão, uma vez que, seu espaço de habitação engendrador do ser feliz, é a cidade. Da mesma forma, o poeta sertanejo só pode cantar, de fato, o sertão, porque é a sua casa protegida, lugar onde as agruras não the atingem com tamanha intensidade capaz de tolher o seu ente; o sertão lhe protege. O sertão tem emergências. O sertão carece, mas o sertão protege.

Em virtude de o Sertão ser o locus em que o sujeito se sente feliz, no poema $O$ vaqueiro, o enunciador prefere seu habitat rural ao luxo da cidade, negando o 


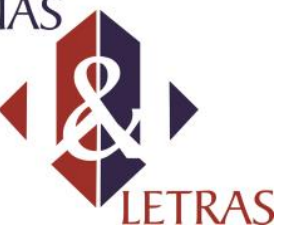

mecanicismo da urbe (alheio-extemporâneo) em detrimento da imensidão íntima (íntimo-sincrônico) da terra que lhe é estendida à contemplação imagética. No poema, o sujeito diz que sua felicidade é maior do que a do doutor que vive coberto de joias e títulos, símbolos da ostentação e da opulência da cidade, que se contrapõem à simplicidade da zona rural.

Sei que o dotô tem riquêza,

É tratado com fineza,

Faz figura de grandeza,

Tem carta e tem anelão,

Tem casa branca jeitosa

E ôtas coisa preciosa;

Mas não goza o quanto goza

Um vaquêro do sertão (ASSARÉ, 2007, p. 57).

Ao vaqueiro, a "casa branca e jeitosa" do doutor não se lhe interessa, pois ela não oferece a proteção que lhe permita sonhar; essa proteção é dada pelo sertão, uma vez que o sujeito lírico dos poemas patativanos está integrado ao seu espaço; há uma imbricação entre o ser e a terra, como bem demonstram os versos de $O$ retrato do sertão.

Desta gente eu vivo perto,

Sou sertanejo da gema

O sertão é o livro aberto

Onde lemos o poema

Da mais rica inspiração.

Vivo dentro do sertão

E o sertão dentro de mim,

Adoro as suas belezas

Que valem mais que as riquezas

Dos reinados de Aladim (ASSARÉ, 2007, p. 103, grifos nossos).

O sujeito-lírico e o sertão estão unidos de tal forma que um alcança a habitar o outro, como se evidencia no excerto anterior. Não é só o indivíduo que mora no sertão, mas, também, o sertão habita nele em um claro processo de permeabilidade imagéticomaterial. Explica-se, aí, o motivo pelo qual o sujeito concebe que o espaço sertanejo valha mais do que as riquezas dos reinados de Aladim; o sertão é a sua casa, o seu abrigo e lhe oferece tudo aquilo que um ser necessita para viver em estado de sonhoprodutor do sentido da existência. A figura do ninho acentua o conforto do sujeito sertanejo.

Meu sertão, meu doce ninho,

De tanta beleza rude,

Volume 18

Número 40 


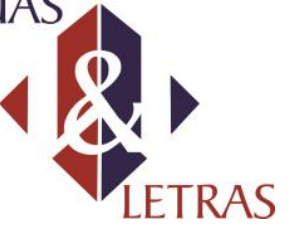

Eu conheço o teu carinho,

Teu amor, tua virtude.

Eu choro triste, com pena,

Ao ver tua morena

Sem letra e sem instrução,

Boa, meiga, alegre e terna

Torcendo um fuso na perna,

Fiando o branco algodão.

Cantei sempre e hei de cantar

O que o meu coração sente,

Para mais compartilhar

Do sofrer da minha gente.

Com rimas de meu canto

Quero enxugar o meu pranto,

Vivendo só na soledade

Com esta gente querida,

Modesta e destituída

De orgulho, inveja e vaidade (ASSARÉ, 2007, p. 102).

Das primitividades imaginárias do habitar, das imagens arquetípicas dos locais de moradia sobre as quais fala Bachelard, as que mais interessam neste trabalho são o ninho, a concha e os cantos. O ninho constitui-se como uma morada, um espaço íntimo. Por esse motivo, o ninho que significa é o que é habitado; aquele que possui seu valor em se constituir como abrigo seguro, como construção singular capaz de superar os artifícios das edificações humanas. Para os pássaros, o ninho sintetiza a morada da vida, a habitação do ser, uma vez que pode, para os filhotes, representar a penugem que lhes falta, oferecendo o calor que lhes é necessário na sua casa primeira.

A imagem construída do ninho, no entanto, pode receber valores humanos, representando o local de abrigo dos homens, oferecendo a segurança necessária para sonhar. É o que ocorre com Quasímodo, personagem de Vitor Hugo a quem se refere Bachelard (2008). Para essa personagem, a catedral se estabelece como seu ninho ${ }^{1}$, onde ela se sente segura, pois, no interior da catedral, encontra os cantos nos quais pode se refugiar, alcançando abrigo protegido dos perigos.

A associação entre o ninho e a catedral se dá porque, assim como a catedral é para Quasímodo; para o pássaro, o ninho é a sua casa. Consoante Bachelard (2008, p. 108), "o ninho vivo, o ninho habitado. O ninho é a casa do pássaro [...] como imagem de repouso, de tranquilidade", associar-se-á "à imagem da casa simples" (BACHELARD, 2008, p. 110). Ocorre, então, uma conjunção entre essas duas imagens - casa e ninho, sendo até possível falar em "casa-ninho", expressão do autor $(2008$, p.

\footnotetext{
${ }^{1}$ Nas palavras de Vitor Hugo (apud BACHELARD, 2008, p. 103), a catedral era para Quasímodo "o ovo, o ninho, a casa, a pátria, o universo".

Volume 18

Número 40
} 


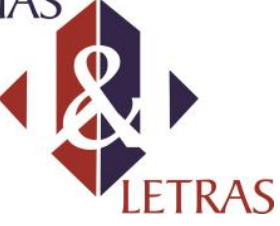

111). Esse espeço marca a naturalidade da função do habitar, constituindo o espaço para o qual sempre se quer voltar, justamente por resguardar o abrigo, o refúgio e, por isso, constituir-se no local de proteção do e para o ser - por estar representando a casa primeira.

\begin{abstract}
A casa-ninho nunca é nova. Poderíamos dizer, de um modo pedante, que ela é o lugar natural da função do habitar. Volta-se a ela, sonha-se voltar como o pássaro volta ao ninho, como a ovelha volta ao aprisco. Esse signo da volta marca infinitos devaneios, pois os regressos humanos acontecem de acordo com o grande ritmo da vida humana, ritmo que atravessa os anos, que luta pelos sonhos contra todas as ausências. Nas imagens aproximadas do ninho e da casa repercute um componente íntimo de fidelidade (BACHELARD, 2008, p. 111, grifos do autor).
\end{abstract}

Ademais, a contemplação do ninho leva o homem à gênese de uma confiança no mundo. A relação sujeito-mundo materializa-se em sonhos edificados quando o autor estende ao leitor o signo do "voltar". O homem é levado à invocação de uma confiança cósmica, acentuando em seu espaço a íntima sensação de pertença. A escuta da invocação ao abrigo frágil do ninho leva o homem à casa onírica; esta que se constitui em um ninho no mundo, onde se pode ter a segurança da casa primeira. Assim,

contemplando o ninho, estamos na origem de uma confiança no mundo, recebemos um aceno de confiança, um apelo à confiança cósmica. O pássaro construiria seu ninho se não tivesse seu instinto de confiança no mundo? Se escutarmos esse apelo, se fizermos desse abrigo precário que é o ninho - paradoxalmente, sem dúvida, mas sobre o próprio impulso da imaginação - um refúgio absoluto, voltaremos às fontes da casa onírica. Nossa casa, captada em seu poder de onirismo, é um ninho no mundo. Nela viveremos com uma confiança nativa se de fato participarmos, em nossos sonhos, da segurança da primeira morada (BACHELARD, 2008, p. 115).

Desde uma compreensão fenomenológica, o sertão passa a ser o ninho do sujeito lírico. Como o ninho é o espaço de proteção para o filhote de pássaro que não possui ainda a seu amparo natural - as penas; o sertão funciona como o ninho que protege o sertanejo. Nesse local, ele se sente seguro, apesar das privações que lhe são impostas ausência de uma educação formal e de outros recursos que lhe permitam uma vida, aos olhos do Outro, mais digna - por causa do seu isolamento dos núcleos civilizacionais mais avançados, retomando-se, desse modo, o significado originário da palavra sertão (BARBOSA, 2000) como o espaço distante e alijado das decisões políticas e do progresso civilizacional. $O$ enunciador, não obstante 'as emergências que se apresentam, brada para que esse espaço de proteção se desenvolva e conquiste as Volume 18

Número 40 


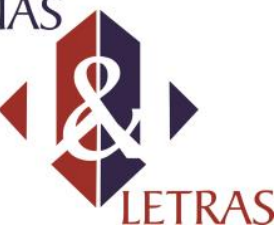

benesses de que gozam os centros urbanos, todavia sem perder sua essência, suas tradições, que são listadas ao longo de $O$ retrato do Sertão. No mesmo poema, o sujeito lírico declara que quer permanecer no sertão. A vontade dele é integrar-se ao seu ninho, pois ali nasceu, é sua primeira casa, e, se abandoná-la, sua essência erosionará. Desterritorializado - afastado da sua casa originária -, o sertanejo deixa de ser o que é, queda-se impossibilitado de sonhar e privado da proteção, perdendo o que o caracteriza: seu espaço de felicidade

Se por capricho de sorte,

Eu sertanejo nasci,

Até chegar a minha morte

Eu hei de viver aqui,

Sempre humilde e paciente

Vendo, do meu sol ardente

E a lua prateada,

Os belos encantos seus

E escutando a voz de Deus

No canto da passarada (ASSARÉ, 2007, p. 100).

O desejo de permanecer no sertão é tanto que, em Eu e o sertão, o sujeito lírico manifesta seu anseio de ficar nesse espaço após sua morte. Não basta, para ele, ter sua sepultura ali. Esse ser sonhador do sertão deseja/quer permanecer vagando por cima de sua casa originária em um processo de desatrelamento matéria/alma. Ele não se importa em cessar seu canto, desde que fique no sertão.

Hoje sou veio e tô vendo

Que já tô perto da morte,

Mas porém, morro dizendo

Que fui caboco de sorte,

Não dou cavaco in morrê,

Somente por conhecê

Qui há tempo ta reservado

In tu, querido sertão,

O meu quadrinho de chão

Pra nele eu sê sepultado.

E mesmo depois de morto,

Mesmo depois de morrê,

Ainda gozo conforto,

Ainda gozo prazê,

Pois, se é verdade que as arma,

Mesmo as que vivero carma

E alcançaro a sarvação,

Fica vagando no espaço,

Os meus caracó eu faço

Pro riba do meu sertão (ASSARÉ, 2007, p. 157-158).

Volume 18

Número 40 


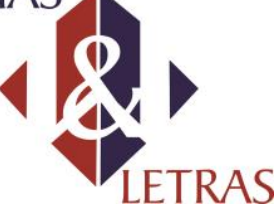

Igualmente ao ninho, a concha, por sua vez, é uma das imagens que concretiza a função do habitar e, a reboque, simboliza a fecundidade que dela se origina. E os devaneios estão na concha habitada e não naquela que foi completamente abandonada. É da concha que o sentido da morte aparece com valor positivo. É importante ressaltar que a concha totalmente desabitada indica a morte do ser. Em outras palavras, o abandono total da concha pelo molusco indica a seu desaparecimento físico, contudo a ideia e a presença que a concha evoca são significativas quando pensamos na verticalidade do valor da habitação, tal qual o poeta que permanece no sertão, embora desmaterializado. Isso fica evidente porque, quando se quer abordar a questão do habitar por meio da imagem poética, a imagem da concha que interessa é a da concha viva, entretanto o vazio da imagem não erosiona o espaço outrora habitado. É isso que confere ao sertanejo, a permanência e o influxo imagético do sertão.

A imagem da concha é uma imagem que espanta, uma vez que "o habitante da concha espanta" (BACHELARD, 2008, p. 119). Além disso, "a imaginação logo fará saírem da concha seres espantosos, seres mais espantosos que a realidade" (BACHELARD, 2008, p. 119), tais espantos são necessários; sem os primeiros espantos, a vida se desgastaria de forma rápida.

Ademais, a admiração é marcada pelo exagero, que pode ser expresso, por exemplo, por meio de imagens como a do elefante saindo de uma concha. Todavia, como alerta Bachelard (2008), pedir que o elefante entre de volta na concha extrapolaria as possibilidades imagéticas, porque a concha participa da fenomenologia do verbo sair. A admiração do grande saindo do pequeno só se dá quando se aceitam os pequenos espantos, uma vez que estes preparam o homem para poder admirar-se, isso quer dizer que quem "aceita os pequenos espantos prepara-se para imaginar os grandes. Na ordem imaginária, torna-se normal que o elefante, o animal imenso, saia de uma concha de caracol. Será excepcional, entretanto, que lhe peçamos, no estilo da imaginação, para entrar nela. [...] O que é belo, o que é grande, dilata os germes" (BACHELARD, 2008, p. 120).

A concha também se constitui como aquela casa que cresce e se constrói, moldando-se de acordo com a medida do seu habitante. O molusco indolente fabrica a sua casa de pedra, compondo, de certa forma, uma casa-concha que instiga nos humanos um devaneio de intimidade, revelando uma espécie de morada natural. E o sertanejo patativano revela sua intimidade semeando-se e enraizando-se no espaço do sertão, erguendo-se sujeito e se olvidando de colher-se. 


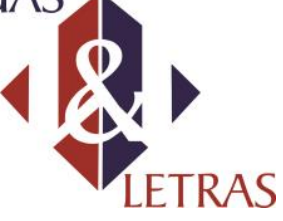

Retomando a fenomenologia do sair, a concha se revela como "um invólucro que se vai abandonar" (BACHELARD, 2008, p. 121). Esse abandonar, no entanto, não se realiza em um todo. O sair do molusco não se realiza na sua completude. Isso se deve porque, mesmo quando deixa a sua casa, o molusco a leva consigo. Para o molusco, assim como para o sertanejo, é impossível pulverizar-se e dar forma a espaços multifacetados porque para onde vão carregam seus deuses domésticos. A concha passa a ter a funcionalidade do habitar que faz com que a casa primeira, a casa natal nos dizeres de Bachelard, acompanhe o ser em sua trajetória durante toda a sua vida, e seu caminho natural é voltar àquele habitar originário.

Para o molusco, é necessário viver para construir a casa e não o contrário. Bachelard ensina que o homem se faz, no seu interior, como um conglomerado de conchas, em que cada órgão possui sua causalidade e, na sua parcialidade, constrói a morada tal qual o molusco fabrica a sua concha. Consoante o autor, poderíamos

dizer que interiormente o homem é um acúmulo de conchas. Cada órgão tem sua causalidade própria, já testada em algum molusco nos longos séculos em que a natureza estava aprendendo a fazer o homem. A função constrói sua forma sobre antigos modelos, a vida parcial constrói sua morada como o molusco constrói a concha" (BACHELARD, 2008, p. 124).

Constitui-se, ainda, a concha como símbolo da ressurreição. Para afirmar isso, Bachelard refere-se ao jesuíta, padre Kircher, que afirma que as conchas marinhas da Sicília que foram reduzidas a pó, quando regadas com água salgada, renascem e se reproduzem. A concha, dessa forma, se faz como uma fênix das águas, sempre a renascer. É importante dizer que "o homem quer aqui habitar uma concha" (BACHELARD, 2008, p.140). Isso se deve ao fato de que o homem busca a morada seja da medida exata, seja da medida perfeita para si. Nas palavras de Bachelard (2008, p. 140), o homem "quer que a parede que protege o seu ser seja inteiriça, polida, fechada como se sua carne sensível devesse tocar as paredes de sua casa".

Antes de entrar na discussão sobre os cantos, imagem importante neste trabalho, é preciso ressaltar que tanto a concha como o ninho funcionalizam os efeitos de sentido do habitar. Potencializam a segurança, o sonho e erguem o sujeito significativo que se dispõe a habitá-lo. Por meio dessas imagens, a imaginação a que o sonhador está habilitado vive a proteção e o refúgio.

Com os ninhos, com as conchas, multiplicamos, sob pena de fatigar a 
elementares, talvez imaginadas longe demais, a função do habitar. Sentimos bem que há um problema misto de imaginação e observação. O estudo positivo dos espaços biológicos não é, naturalmente, o nosso problema. Queremos simplesmente mostrar que quando a vida se abriga, se protege, se cobre, se oculta, a imaginação simpatiza com o ser que habita o espaço protegido. A imaginação vive a proteção, em todas as nuanças de segurança, desde a vida nas conchas materiais até as mais sutis dissimulações no simples mimetismos das superfícies (BACHELARD, 2008, p. 141).

Bachelard (2008), reforçando o já dito, nos ensina que a concha participa da fenomenologia do verbo sair e que ela (a concha) é "um invólucro que se vai abandonar!" (BACHELARD, 2008, p. 121). Entretanto, o molusco sai da concha, mas não a abandona totalmente, pois continua a carregá-la consigo. Da mesma forma, ocorre com o sertanejo do poema $E u$ e o sertão, emblemática composição patativana, anteriormente, citada; ele morre e sai do Sertão, mas, paradoxalmente, continua nele. Como declara o próprio sujeito lírico, ele não tem receio de morrer, uma vez que sabe que sua sepultura está reservada em solo sertanejo. Ademais, sua permanência é garantida pela crença que diz que as almas, após a morte, permanecem vagando sobre a terra em que viveram. Dessa forma, se, enquanto vivo, o sertanejo vive com os pés na sua terra, após a morte, ele permanece sob e sobre o sertão - sob, com seu corpo sepultado no solo em que viveu; sobre, ao vagar por cima da sua terra querida.

Outro espaço protegido, como o ninho e a concha, onde a imaginação encontra a proteção, é o canto. Este resguarda o ser, constituindo-se como a casa deste, pois "todo canto de casa, todo ângulo de um quarto, todo espaço reduzido de onde gostamos de encolher-nos, de recolher-nos em nós mesmos, é, para a imaginação, uma solidão, ou seja, o germe de um quarto, o germe de uma casa" (BACHELARD, 2008, p. 145). O canto constitui-se em um refúgio por assegurar ao ser o valor da imobilidade. A criança quando entristece vai a um canto em sofrimento calado ressignificar-se como sujeito daquele espaço e tempo. A imobilidade garante ao ser um local seguro, um local próximo ao seu não deslocamento. Do canto, advém a percepção de se estar em paz, fazendo com que um quarto imaginário se construa ao redor do corpo humano.

o canto é um refúgio que assegura um primeiro valor do ser: a imobilidade. Ele é o local seguro, o local próximo da imobilidade. O canto é uma espécie de meia-caixa, metade paredes metade porta. [...] A consciência de estar em paz em seu canto propaga, por assim dizer, uma imobilidade. A imobilidade irradia-se. Um quarto imaginário se constrói ao redor do nosso corpo, que acreditamos estar bem escondido quando nos refugiamos num canto" (BACHELARD, 2008, p. 146).

Volume 18

Número 40 


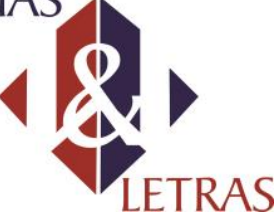

Ao ensinar que o canto é uma meia-caixa com uma metade de paredes, e, uma metade outra, de porta, Bachelard sugere uma duplicidade para o canto. Ao mesmo tempo, o canto é fechamento e abertura. É fechamento por se apresentar como local de refúgio, de proteção e recolhimento. Entretanto, ao mesmo tempo, é abertura; com a sua porta, o canto abre o ser para o mundo, que pode vir a se constituir em uma imagem ampliada da casa primordial. Em outras palavras, no que se refere à abertura, o canto pode ser interpretado como uma miniatura do mundo. $\mathrm{O}$ canto funciona também como síntese entre a casa natal e a casa onírica. Na solidão do canto, é que o homem, quando habilitado como sonhador, encontra a talvez já esquecida casa velha de sua infância e, consegue mediá-la com a casa onírica, unindo-as em uma única imagem, tornando a materialidade em silêncio, porque é

do fundo do canto, [que] o sonhador recorda todos os objetos de solidão, os objetos que são lembranças de solidão e que são traídos unicamente pelo esquecimento, abandonados num canto. [...] Do fundo de seu canto, o sonhador revê uma casa mais velha, a casa de uma outra região, fazendo assim uma síntese entre a casa natal e a casa onírica" (BACHELARD, 2008, p. 151).

O Sertão imagetiza a obra patativana como um canto de proteção. Assim como a criança foge a fim de esconder em um canto da casa, tangenciando suas transgressões iamginárias, conferindo a esse local o status de proteção, o sertanejo também percebe o Sertão como esse canto em que se vê protegido dos males que podem lhe acometer. Por esse motivo, é que, em Retrato do Sertão, esse espaço é nomeado com o diminutivo cantinho. É preciso ressaltar, inclusive, que o uso do sufixo diminutivo -inho, na palavra canto, reforça a relação emotiva entre o sujeito figurado nos poemas e seu local de habitação, o que fica latente ao se perceber que o vocábulo utilizado como rima para cantinho é justamente carinho.

Se o poeta marinheiro

Canta as beleza do mar,

Como poeta roceiro

Quero meu sertão cantar

Com respeito e com carinho.

Meu abrigo, meu cantinho,

Onde viveram meus pais.

O mais puro amor dedico

Ao meu sertão caro e rico

De belezas naturais (ASSARÉ, 2007, p. 99).

Volume 18

Número 40 


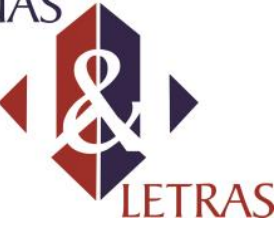

O filósofo compreende como possível habitar o espaço da palavra. Essa interpretação advém da comparação que o fenomenólogo faz da palavra com a casa, afirmando que, assim como esta, aquela possui seu sótão e seu porão.

As palavras - imagino isso frequentemente - são casinhas com porão e sótão. O sentido comum reside no rés-do-chão, sempre pronto para o 'comércio exterior', no mesmo nível de um outrem, desse transeunte que nunca é um sonhador. Subir a escada da palavra é, de degrau em degrau, abstrair. Descer ao porão é sonhar, é perder-se nos distantes corredores de uma etimologia incerta, é procurar nas palavras tesouros inencontráveis. Subir e descer nas palavras é a vida do poeta. Subir muito alto, descer muito baixo é permitido ao poeta que une o terrestre ao aéreo (BACHELARD, 2008, p. 155).

Essa compreensão de Bachelard aproxima-se à de Cassirer (1972), quando afirma que a palavra funciona como uma arquipotência em que se manifestam formas de o ser habitar o espaço. Para o autor, a palavra quando enunciada pelo ser que a canta, adquire uma força sensível e se coloca, então, como uma arquipotência ritualizável. Por essa razão, os poemas do corpus e detentor de um poder ritualístico engendrado pelo signo. Todavia, antes de encerrar essa reflexão sobre a poética do espaço de Patativa do Assaré, é necessário reafirmar algumas pressuposições acerca de alguns poemas, reforçando a posição aqui contemplada.

Em O poeta da roça, o sujeito lírico faz questão, ao se colocar como poeta, de se opor a cantadores e poetas errantes, que não se fixam ao seu local. Isso mostra o desejo do enunciador em permanecer no Sertão, que constitui sua casa, onde pode viver todas as potencialidades do imaginário sertanejo.

\author{
Sou poeta das brenha, não faço o papé \\ De argum menestré, ou errante cantô \\ Que veve vagando, com sua viola, \\ Cantando, pachola, à percura de amô (ASSARÉ, 2007, p. 21).
}

Vida sertaneja, por sua vez, mostra que o Sertão é o local de habitar do indivíduo. Isso faz com que em Eu e o sertão, o eu lírico componha um hino de amor ao seu locus vivendi. No sertão, tudo apresenta-se imageticamente naturalizado e permite que o sertanejo viva na proteção da casa originária, constituído como um espaço feliz, podendo ser vislumbrado à luz da topofilia proposta por Bachelard em sua poética. 


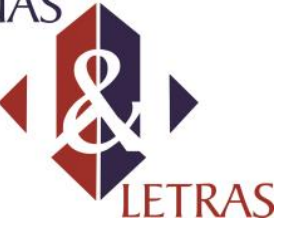

\section{CONSIDERAÇÕES FINAIS}

Ao largo do texto, buscamos mostrar a importância do espaço do sertão para o sujeito sertanejo, mesmo que a condição humana material acentue as mazelas sociais analfabetismo, fome, descaso político -, o sertão é o espaço de proteção, o que fica evidente se pensarmos na figuração dos sujeitos erguidos e representados nos poemas. O sertão é compreendido como espaço protegido/protetor para as vozes que habitam a palavra na poética do poeta nordestino. Esse locus guarda a essencialidade da casa como imagem de abrigo tal qual compreende Bachelard (2008). Dessa maneira, o sertão é representado em uma duplicidade na poética de Patativa do Assaré. Se, por um lado, ele possui suas máculas e chagas evidenciadoras das emergências da ossatura social, por outro, representa o espaço feliz, a topofilia bachelardiana, em que o sujeito vive todas as potencialidades do sonho e do devaneio e, por esse motivo, quer nele permanecer. Essa permanência é tão intensa que o sujeito enunciador declara que não se importa com a morte, com o fim da matéria corpórea; a ele não importa cessar seu canto, desde que permaneça naquele espaço. Assim, podemos observar que se evidenciou, categoricamente, como o sertão se caracteriza como espaço de proteção do sertanejo na acepção bachelardiana de casa e como se representa na poética patativana.

\section{REFERÊNCIAS}

ASSARÉ, Patativa. Cante lá que eu canto cá: filosofia de um trovador nordestino. 14. ed. Petrópolis: Vozes, 2004.

. Antologia poética. 5. ed. Fortaleza: Demócrito Rocha, 2007.

BACHELARD, Gaston. A poética do espaço. São Paulo: Martins Fontes, 2008.

CASSIRER, Ernst. Linguagem e mito. São Paulo: Perspectiva, 1972.

CASSIRER, Ernst. Mito do Estado. São Paulo: Perspectiva, 1979.

DIAS, Gonçalves. Canção do exílio. In: GONÇALVES, Magaly Trindade et al. (Org.). Antologia das antologias. São Paulo: Musa, 1995. 